ーコミュニケーションー

\title{
$\mathrm{Cu}_{\times} \mathbf{M o}_{6} \mathbf{S}_{7.8}$ 電極の酸化還元インタカレーション
}

\author{
井上徹 ${ }^{*}$, 山 瀬 利 博
}

Redox Intercalation Behaviour of $\mathrm{Cu}_{\times} \mathrm{Mo}_{6} \mathrm{~S}_{7.8}$

Tooru INOLE*and Toshihiro YAMASE

Received July 8, 1986 ; Accepted July 31, 1986

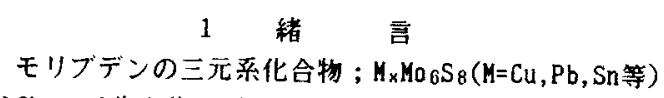
はChevrel化合物と呼ばれている。1971年にChevrelが 合成して以来、新しい超伝導材料として盛んに研究され ており、高い䀦界温度Tc、および高い腹界磁場强度Hcを 示す物筫の一つである。11この化合物の結晶棈造は、 Moの八面体クラスターがSの立方体中に内包された規則 的な配列をしており、金属MはSの立方体間に生じる間隙 に存在する。金属以の種類や組成比昍違いによってTC 及びHcの物性が変化することが報告されている。21

本研究においては、CU.Ho6 $\mathrm{S}_{7.8}$ 電極としてCuイオン のインタカレーションを伴う酸化量元挙動と践造変化に ついて報告する。

\section{2 実殹}

$\mathrm{Cu}_{x} \mathrm{M}_{6} \mathrm{~S}_{7.8}$ の合成は、高純度(約99.99\%)OCuS, MoS 2 , Moの粉末を任意の比でよく混合し、300 kg/ $\mathrm{cm}^{2} て ゙$ 加圧成 型し、石英管内に真空封入した後、電気炉中で $1000{ }^{\circ} \mathrm{C}$ 、 100 時間焼成して行った。3) 試料にCu線を銀ペースト で結線して電極とした。電解液はN2通気により脱気

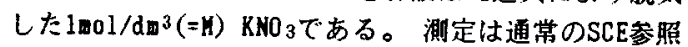
電極を用いる三電極四端子方式で電位補償して行った。 生成物は試料をディスク、Pt在リングとする回転電極 $(R$ $\mathrm{RDE}$ )法、および分光法により分析した。4) 電解前俊の 結晶抟造の変化は粉末線回折法により測定した。

\section{3 結果と考察}

$\mathrm{KNO}_{3}$ 溶液中における的 $4 \mathrm{HO}_{6} \mathrm{~S}_{7}$.8かららなる静止電極の電 流一電位曲線をFig.1に示す。 -1.0 から0.3 V VS.SCEの 電位籍囲[A]においてブロードな酸化摆元波が見られる。 また、0.3 以以上の筙囲[B]で、さらに别の酸化波か現れ

東京工業大学資源化学研究所 ( 1227 横浜市粶区 长津田町 4259 ) Besearch Laboratories of Resources Utilization, Tokyo Institute of Technology (4259 Nagat suta-cho, Midori-ku, Yokohama, 227)

Key Words: Intercalation, Molybdenum Sulfide
る。酸化反応に伴い溶夜は黄粶色に変化して来た。 これらの電流值は組成比的の堷加とともに增加していた。

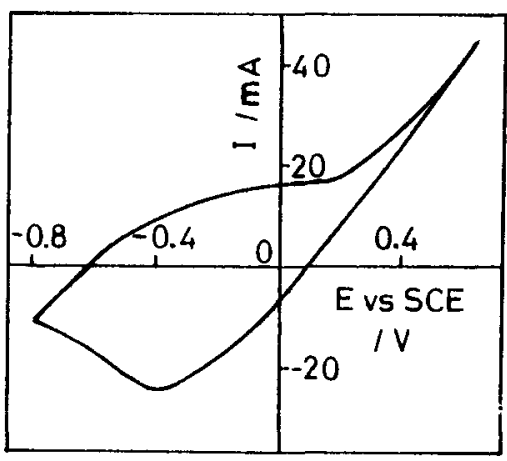

Fig. 1 Current-potential curve of CuaMos 7.8 in $1 \mathrm{M} \mathrm{KNO}_{3}$ solution.

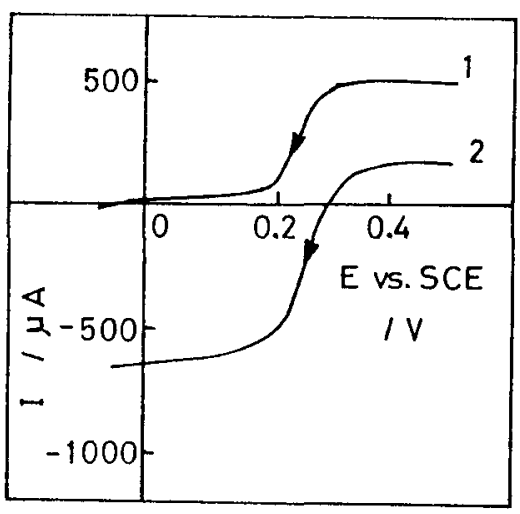

Fig. 2 Current-potential curves at Pt ring electrode in the course of $\mathrm{Cu}_{4} \mathrm{Mo}_{6} \mathrm{~S}$ ?. 8 oxidation at a disk at $1000 \mathrm{rpm}$ in $1 \mathrm{~K} \mathrm{KCl}$ solution.

(1) $E_{d i s k}=-0.2 \mathrm{~V}, I_{d i s k}=2.5 \mathrm{~mA}$,

(2) $E_{d i s t:}=0.35 V, I_{d i s k}=5.2 \mathrm{~mA}$. 


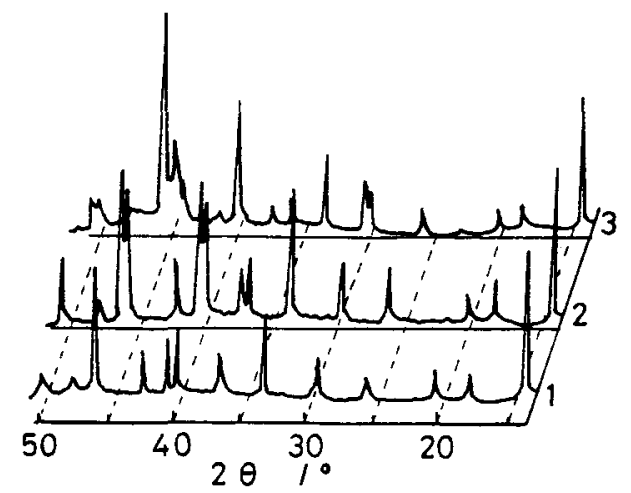

Fig. 3 X-Ray diffraction patterns of oxidized $\mathrm{Cu}_{x} \mathrm{Mos}_{6} \mathrm{~s}$.

(1) $\mathrm{Cu}_{4} \mathrm{Ho}_{6} \mathrm{~S}_{7} .8$,

(2) $10 \mathrm{C}$ oxidized,

(3) 30 C oxidized.

これらの酸化遑元反応の生成物を回転電極法で調べた。 $\mathrm{Cu}_{4} \mathrm{M}_{0} \mathrm{~S}_{7} \mathrm{r} .8$ ディスク電極上での酸化生成物をリング電極 で模出した結果をFig.2に示す。ここで、RRDEの理論補 捉率社，および実際の補捉率Naは、それぞれ $27 \%$ と20\% であった。 0.2 付近の波はCu+/2+の酸化道元波であ ク、酸化生成物は電位籁囲 [A]ではCU+、電位範国 はCu2+が主であり、邊元反応はCu+の係わる反応である と考えられる。また、マクロ電解による溶液中のCu+, Cu2+のポーラログラッフィク分析および吸収スペクトル 分析からもCu+ $\mathrm{Cu}^{2+}$ の変化が確珰された。組成比が 2く娢くにおいても同粎な挙動が觀測された。これらの 結果より、Cu* $\mathrm{HOB}_{6} \mathrm{~S}_{7.8}$ の酸化僄元反応は次のように書け る。電位Eが、 $-1.0<E<0.3 \vee$ vs. SCEでは

$$
\begin{aligned}
& \mathrm{Cu}_{4} \mathrm{H}_{6} \mathrm{SS}_{7.8} \rightleftharpoons \mathrm{Cu}_{3} \mathrm{HO}_{6} \mathrm{~S}_{7.8}+\mathrm{Cu}^{+}+\mathrm{e}^{-} \\
& \mathrm{Cu}_{3} \mathrm{H}_{6} \mathrm{~S}_{7.8} \rightleftharpoons \mathrm{Cu}_{2} \mathrm{Ho}_{6} \mathrm{SS}_{7.8}+\mathrm{Cu}^{+}+e^{-}
\end{aligned}
$$

となるインタカレーション反応である。 $0.3 \mathrm{~V}<\mathrm{E} て ゙$ 泳、

$$
\mathrm{Cu}_{x} \mathrm{Mo}_{6} \mathrm{~S}_{7.8} \rightarrow \mathrm{Cu}_{x-1} \mathrm{Mo}_{6} \mathrm{~S}_{7.8}+\mathrm{Cu}^{2+}+2 \mathrm{e}^{-}
$$

となるCu2+の浴出反応である。

このとき、Sの洒数を-2とすれば、Moの価数ZはCu+の インタカレーションによって、1.93<Z<2.67の籍团で変 化している。この電荷の增诚により結晶搆造の変化が 予想される。Fig.3にディインタカレーションに伴う試 料の線回折結果を示す。酸化の電気量の増加に従って

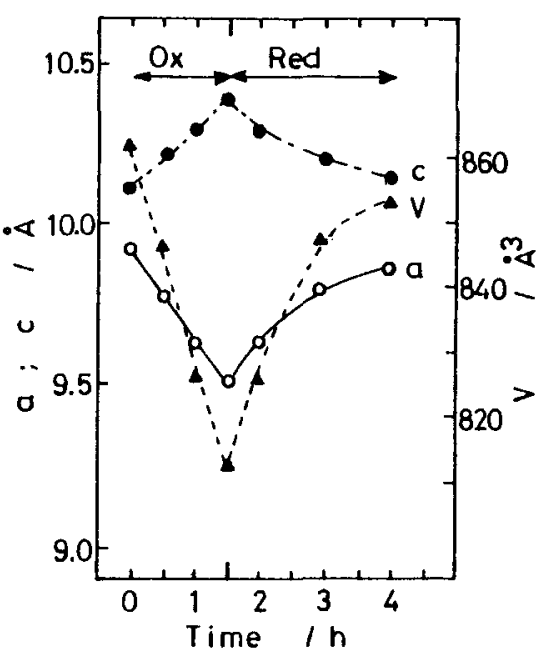

Fig.4 Structure change due to redox intercalation.

六方晶の構造が変化していることがわかる。䄪和 CuCI

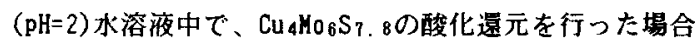
の結晶構造変化の結果をFig.4に示す。六方晶単位格子 の格子定数a,cおよび体積りは、酸化息元の電気量の変化 に従って变化し、かつ可逆的であることが確認された。

$$
4 \text { ま と }
$$

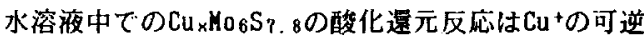
的なインタカレーション過程とCu2+の溶出過程がある。 インタカレーション過程における結晶の構造変化も電気 量に䧇存し、可逆的であった。酸化嗃元処理注任意の

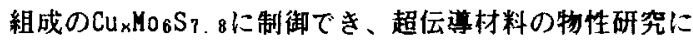
有効であることがわかった。

本研究を行うにあたり、費重な御助言を睗りました、 果工大工学部 脇原将孝助教授に感謝いたします。

\section{文献}

1) R. Chevrel and M. Sergent, in "Topics in Current Physics," vol. 32, eds. O. Fischer and M. B. Maple, pp. 25-86, Springer-Verlag, Berlin (1982).

2) $K$. Yvon, in "Current Topics in Materials Science," vol. 3, ed. E. Kaldis, pp. 53-129, Elsevier, Amsterdam (1979).

3) S. Yamamoto, K. Matsui, M. Wakihara, and M. Taniguchi, Mat. Res. Bull., 181311 (1983).

4）滕嶋 昭、相沢益男、井上䇖、『電気化学測定法』 技報堂、( 1984$)$ 。 